DOI: 10.26907/2074-0239-2020-60-2-218-222

УДК $82-31$

\author{
ЖЕНСКИЕ ОБРАЗЫ \\ В «ЗАПИСКАХ ЮНОГО ВРАЧА» М. А. БУЛГАКОВА
}

(C) Ким Сунггеон

\title{
WOMEN'S IMAGES IN “NOTES OF A YOUNG DOCTOR” BY M. BULGAKOV
}

\begin{abstract}
Kim Sunggeon
The article studies the features of female images in M. Bulgakov's cycle of stories "Notes of a Young Doctor". We address this topic to clarify the typology of female images in the writer's work. The main purpose of the study is to indicate how Bulgakov's early work represents the basic features of female nature, realized in his subsequent work. The theme of the main character's professional and personal formation, central to the cycle "Notes of a Young Doctor", includes the motif of "knowing a woman", realized not through the protagonist's love experiences, but through his discovery of the female nature as different from the male one. The study of the cycle "Notes of a Young Doctor" gives reason to argue that initially the category "female" is understood by Bulgakov multidimensionally. On the one hand, this is a woman's fragility, reinforced by the writer's idea that modern reality is apocalyptic. Two variants for emphasizing this fragility are indicated: the image of a young woman, a girl as the bearer of beauty, and the image of a mother as the giver of life. In the times of trouble and historical cataclysms and in the hard changing circumstances of remote provincial life, both female natures are constantly at risk, on the verge of death, which is expressed in the suffering and death of women. On the other hand, the woman in the series "Notes of a Young Doctor" embodies both the dark power of instinct and inertia. The result of the study is the assertion that a woman's nature includes a spontaneous-instinctive and sublimely humane principle. The first is inextricably linked with the nature of a woman as a continuer of the clan and carries both strength and danger. The second - becomes a manifestation of true motherhood as the embodiment of selfless love.
\end{abstract}

Keywords: M. Bulgakov, female images, typology, Russian literature of the twentieth century, image of mother, demonism.

Статья посвящена исследованию специфики женских образов в цикле рассказов «Записки юного врача» М. А. Булгакова. Обращение к данной теме связано с необходимостью уточнения типологии женских образов в творчестве писателя. Основная цель исследования - рассмотреть, как в раннем произведении Булгакова проявляются основные характеристики женской сущности, которые реализовались в его последующем творчестве. Тема профессионального и личностного становления героя, центральная для цикла «Записки юного врача», включает в себя и мотив «познания женщины», реализуемый не в любовных переживаниях героя, а в открытии им женского как иного, отличного от мужского. Исследование цикла «Записки юного врача» дает основание утверждать, что изначально категория «женское» понимается Булгаковым многомерно. С одной стороны, это ощущение хрупкости женщины, усиленное представлением о современной писателю реальности как апокалипсической. Обозначены два варианта акцентирования этой хрупкости: образ юной женщины, девочки как носительницы красоты и образ матери как родоначальницы жизни. И те, и другие начала в смутные времена исторических катаклизмов и в то же время в трудно меняющихся обстоятельствах глухой провинциальной жизни постоянно подвергаются опасности, оказываются на пороге гибели, что выражается в страданиях и смертях женщин. С другой стороны, женщина в цикле «Записки юного врача» воплощает в себе и темную силу инстинкта, и косность. Итогом исследования является утверждение, что сущность женщины включает в себя стихийно-инстинктивное и возвышенно-гуманное начала. Первое неизбывно связано с природой женщины как продолжательницы рода и несет в себе и силу, и опасность. Второе - становится проявлением истинного материнства как воплощения бескорыстной любви.

Ключевые слова: М. А. Булгаков, женские образы, типология, русская литература XX века, образ матери, демонизм. 
Женские образы в творчестве М. А. Булгакова уже становились предметом внимания исследователей. Однако преимущественно это внимание было направлено на те из них, в которых ярко проявило себя демоническое начало. Так, в работе Г. Л. Нефагиной «Демоническое начало женских образов М. Булгакова» проявление демонического в женщине связывается с характером ее воздействия на мужчину, что позволяет автору выделить три типа: роковая женщинаразрушительница, муза - мучительница или спасительница, вдохновляющая творческую личность, женщина-вамп - потребительница, использующая свои чары для собственной выгоды [Нефагина]. Л. Я. Бобрицких в статье «О традиции женского демонизма серебряного века в романе М. Булгакова „Белая гвардия“» отмечает, что главной чертой такого образа является «гибельное искушение любовью» [Бобрицких, с. 214], и вслед за другими исследователями творчества писателя, прежде всего Е. А. Яблоковым, высказывает важную мысль об амбивалентности женских образов у писателя, включающих в себя и светлые, и темные начала. В. А. Коханова в своей работе «Архетип женщины в романе М. А. Булгакова „Белая гвардия“"» тоже говорит о том, что женщина у Булгакова может и спасти, и погубить мужчину, но связывает эту амбивалентность с апокалипсическим характером эпохи.

На наш взгляд, исследование женских образов в цикле М. А. Булгакова «Записки юного врача» помогает преодолеть определенную жесткость типологии, которая определилась на сегодняшний день в булгаковедении и согласно которой большинство исследователей выделяют в творчестве писателя два ведущих женских типа: матери и демонической женщины. Кроме того, это позволит увидеть, как уже в этих ранних рассказах обозначились характерные для писателя аспекты размышления о сущности женского начала.

Исследователи выделяют в «Записках юного врача» главную тему - становления героя и в профессиональном, и в личностном плане. Оно происходит и в погружении в другую, чуждую для него жизнь, и в выстраивании отношений с людьми. Е. А. Яблоков в статье «,Воет в трубе истинный Бог, как дитя..." (Мифопоэтика рассказа М. А. Булгакова „Стальное горло“)» утверждает, что в цикле выстроен системный мифологический подтекст, и в связи с этим собственно метасюжет его можно рассматривать как инициацию героя [Яблоков]. Исходя из этого, можно утверждать, что частью такой инициации становится и своеобразное «познание женщины». В цикле отсутствует история любовных пе- реживаний, что в целом нехарактерно для произведений, отображающих юные годы героев. Но именно их отсутствие позволяет юному доктору увидеть женщину не столько как объект страсти, сколько как человеческое существо с иной сущностью. Своеобразный путь такого открытия прочерчен в первом рассказе цикла «Полотенце с петухом». Оказавшаяся на операционном столе умирающая прекрасная девушка для героя, взявшегося за почти безнадежную операцию, только объект приложения сил. Поэтому молодой врач воспринимает не женскую, а человеческую ее сущность:

«Вот как потухает изорванный человек, - подумал я, - тут уж ничего не сделаешь...» [Булгаков, с. 481].

\section{И далее:}

«...сейчас мне придется в первый раз в жизни на угасающем человеке делать ампутацию. И человек этот умрет под ножом» [Там же].

И даже отмеченная им красота девушки затмевается симптомами близкой смерти. А финал рассказа как будто намечает начало несбывшегося романа: герой воспринимает очарование ее красоты и смущается, целуя вместо губ в нос. Символичен в этом смысле и подарок, преподнесенный девушкой, - вышитое полотенце, которое традиционно дарилось невестой будущему жениху.

Одной из сторон восприятия женщины в «Записках юного врача» становится ощущение ее хрупкости. Оно усиливается атмосферой отображаемой реальности, которая предстает как апокалипсическая. Об этом вслед за Б. М. Гаспаровым, утверждающим, что в основе конструкции художественного мира писателя лежит Новый Завет, пишет Е. И. Ерохов в статье «Апокалиптические мотивы в цикле рассказов М. А. Булгакова „Записки юного врача“». Исследователь выявляет в текстах рассказов писателя такие апокалипсические мотивы, как болезнь, тьма, воскресение из мертвых, зверь и болезнь [Ерохов].

Представление о хрупкости женщины выражено в двух вариантах образов. Первый вариант - это образ юной женщины, девочки, которая становится носительницей необыкновенной красоты. Так, в рассказах «Полотенце с петухом», о котором уже говорилось выше, и «Стальное горло» появляются образы девочек, находящихся на пороге жизни и смерти. Обе они отмечены удивительной женской привлекательностью. В первом произведении она обозначена через впечатление рассказчика: 
«На белом лице у нее, как гипсовая, неподвижная, потухала действительно редкостная красота. Не всегда, не часто встретишь такое лицо» [Булгаков, с. 480].

Во втором появляется подробное описание:

«Только на конфетных коробках рисуют таких детей - волосы сами от природы вьются в крупные кольца почти спелой ржи. Глаза синие, громаднейшие, щеки кукольные. Ангелов так рисовали» [Там же, с. 487].

Подчеркивание неправдоподобности этой удивительной привлекательности («на конфетныхх коробках», «ангелов так рисовали») усиливает ощущение трагизма, когда смерть не только губит человека, но отнимает у мира красоту. Романтический характер такого представления о красоте определяется тем, что в ее воссоздании писатель уходит от акцентирования телесности, что в целом является характерной чертой описаний в цикле.

Тема воздействия этой красоты здесь только косвенно намечена и реализуется в ином ключе, чем в последующем творчестве писателя. Во многом именно она побуждает героя действовать в совершенно безнадежных с медицинской точки зрения ситуациях, что вызывает удивление и недоумение у окружающих. Это позволяет говорить о том, что красота рассматривается здесь не в аспекте силы, оказывающей спасительное или разрушительное воздействие, а как ценность, которую нужно сохранить и которая, возможно, в последующем тоже позволит преодолеть «тьму египетскую».

Мотив хрупкости женского выражается и в образе материнства. В этом цикле матери выступают в роли мучениц. Они либо страдают из-за болезни и смерти детей, как это происходит в рассказах «Стальное горло», «Вьюга», «Звездная сыпь», либо умирают во время родов. Характерно, что молодой врач, постоянно испытывающий страх от своей неопытности, перебирающий в своем сознании трудные случаи, с которыми ему придется столкнуться, прежде всего думает о родах и неправильных положениях плода.

Однако женское изображается писателем и с другой стороны. Женщина раскрывается здесь не столько в своей всепоглощающей любви к ребенку, сколько в безжалостности и неумолимости проявления материнского инстинкта. В рассказе «Стальное горло» герой открывает для себя суть этой фактически животной связи матери с ребенком. Произведение открывается картиной «ноябрьской тьмы с вертящимся снегом» [Там же, с. 486]. Этот «метельный» мотив пронизывает весь цикл, неся в себе разные смыслы. Однако в этом рассказе с его помощью символически обозначается то темное, стихийное начало, которое в последующем осмыслении писателя несло в себе хаос и разрушение.

Опасность доминирования инстинктивного выражена через повторяющийся мотив смерти матери, которую может повлечь за собой гибель дочери. Вначале героиня заявляет о том, что если ее дочь умрет, то она покончит жизнь самоубийством, а затем звучат ее слова о том, что при трагическом исходе ее убьет муж.

Поведение этой женщины, интонации ее голоса пугают героя. Он видит в ней это темное стихийное естество, которое способно поглотить все разумное:

«- Что ж, значит, помрет она? - глядя на меня, как мне показалось, с черной яростью, спросила мать» [Там же, с. 488];

«Мать же крикнула мне нехорошим голосом» [Там же].

И уже спасший девочку от неминуемой гибели, герой, видя реакцию матери, замечает:

«Глаза у нее были как у дикого зверя. <..> Когда я услышал звук ее голоса, пот потек у меня по спине, я только тогда сообразил, что было бы, если бы Лидка умерла на столе» [Там же, с. 493].

В противоположность этому носительницами истинно материнского начала в рассказах выступают акушерки Анна Николаевна и Пелагея Ивановна по отношению к самому герою. В рассказе «Полотенце с петухом» отношения между ними проходят стадии непонимания, обиды и, наконец, обретения способности действовать совместно:

«Капли пота неудержимо бежали у меня по лбу из-под белого колпака, и марлей Пелагея Ивановна вытирала соленый пот. В остатках крови в жилах у девушки теперь плавал и кофеин. Нужно было его впрыскивать или нет? На бедрах Анна Николаевна, чуть-чуть касаясь, гладила бугры, набухшие от физиологического раствора. А девушка жила» [Там же].

Они поощряют его и гордятся достижениями на его медицинском поприще. В рассказах несколько раз повторяется ситуация, когда, услышав похвалу в свой адрес, герой принимает ее за насмешку, но убеждается, что выраженное чувство неподдельно:

«Сквозь сон и пелену пота, застилавшую мне глаза, я видел счастливые лица акушерок, и одна из них мне сказала: 

цию.

- Ну и блестяще же вы сделали, доктор, опера-

Я подумал, что она смеется надо мной, и мрачно, исподлобья глянул на нее» [Там же].

Как видим, уже в этом цикле Булгаков размышляет о соотношении инстинктивного и возвышенно-гуманного в любви и делает выбор в пользу последнего. И это впоследствии ведет его к созданию образов героинь, у которых отсутствие детей сочетается с выраженной способностью к самопожертвованию и милосердию. Именно такими становятся Елена в романе «Белая гвардия» и Маргарита в романе «Мастер и Маргарита».

Женщина открывается герою в рассказах цикла и как воплощение косности. В этом плане характерен рассказ «Тьма египетская», название которого очевидно символическое. Образ молодой женщины, не желающей прислушиваться к советам врача и упрямо поступающей по-своему, воплощает суть косного сознания, инертного в своей основе, ориентированного на повседневное существование. Авторские ремарки подчеркивают ограниченность такого типа сознания: «запела льстиво» [Там же, с. 518], «пела бабочка сдобным голосом», «умильно попросила баба» [Там же, с. 519]. Именно после посещения этой бабы между врачом, фельдшером и его помощницами-акушерками разворачивается оживленный разговор о диких обычаях повивальных бабок, о невежестве и темноте.

Именно с этим, на наш взгляд, связана только намечающаяся в этом цикле тема женского демонизма. Она реализуется затем в рассказе «Морфий», где возникают две ипостаси демонического: оперная певица, которая бросает героя и косвенно виновна в его последующем пагубном пристрастии к морфию, и старушонка из его наркотического видения.

Таким образом, в цикле рассказов М. А. Булгакова «Записки юного врача» важной стороной раскрывающейся темы становления героя является постижение им женского начала, которое проявляется и в красоте юности, и в тайне материнства. С ними связано ощущение хрупкости женщины, существующей в распадающемся мире. Однако уже в ранних произведениях писателя герою открывается амбивалентная сущность женщины, другими сторонами которой становятся косность и власть инстинкта.

\section{Список литературы}

Бобрицких Л. Я. О традиции женского демонизма серебряного века в романе М. Булгакова Белая гвардия // Михаил Булгаков, его время и мы / под ред.
Гжегожа Пшебинды и Януша Свежего. Краков, 2012. C. 213-224.

Булгаков М. А. Белая гвардия. Жизнь господина де Мольера. Рассказы. М.: Правда, 1989. 576 с.

Ерохов Е. И. Апокалиптические мотивы в цикле рассказов М. А. Булгакова «Записки юного врача» // Современные исследования социальных проблем (электронный научный журнал). 2015. № 8. С. 151158.

Коханова В. А. Архетип женщины в романе М. А. Булгакова «Белая гвардия». Вестник Московского государственного областного университета. Серия: «Русская филология». 2007. № 2. 2007. С. 159-166.

Нефагина Г. Л. Демоническое начало женских образов М. Булгакова // Русский язык в зеркале переводов. 2016. С. 359-367.

Яблоков E. A. «Воет в трубе истинный Бог, как дитя...» (Мифопоэтика рассказа М. А. Булгакова «Стальное горло»). URL: https://cyberleninka.ru article/ n/voet-v-trube-istinnyy-bog-kak-ditya-mifopoetikarasskaza-m-a-bulgakova-stalnoe-gorlo/viewer (дата обращения: 01.06.2020).

\section{References}

Bobritsky, L. Ia. (2012). O traditsii zhenskogo demonizma serebrianogo veka $v$ romane M. Bulgakova "Belaja gvardiia" [On the Tradition of Female Demonism of the Silver Age in the Novel by M. Bulgakov "The White Guard"]. Mihail Bulgakov, ego vremia i my. Pod red. Gzhegozha Pshebindy i Ianusha Svezhego, pp. 213224. Krakow. (In Russian)

Bulgakov, M. A. (1989). Belaia gvardiia. Zhizn' gospodina de Mol'era. Rasskazy [The White Guard. The Life of M. de Moliere. Stories]. 576 p. Moscow, Pravda. (In Russian)

Erokhov, E. M. (2015). Apokalipticheskie motivy v tsikle rasskazov $M$. A. Bulgakova "Zapiski junogo vracha" [Apocalyptic Motifs in the Cycle of Stories by M. A. Bulgakov "Notes of a Young Doctor"]. Sovremennye issledovaniia social'nyh problem (elektronnyi nauchnyi zhurnal), No. 8, pp. 151-158. (In Russian)

Iablokov, E. A. "Voiet v trube istinnyy Bog, kak ditia..." (Mifopoetika rasskaza M. A. Bulgakova "Stal'noie gorlo") ["It Howls in a Pipe, Good God, as a Child ..." (Mythopoetics of Mikhail Bulgakov's Story "A Steel Throat")]. URL: https://cyberleninka.ru/article/n/ voet-v-trube-istinnyy-bog-kak-ditya-mifopoetika-

rasskaza-m-a-bulgakova-stalnoe-gorlo/viewer (accessed 1.06.2020). (In Russian)

Kokhanova, V. A. (2007). Arhetip zhenshhiny v romane M.A. Bulgakova "Belaia gvardiia" [The Archetype of a Woman in M. Bulgakov's Novel "The White Guard"]. Vestnik Moskovskogo gosudarstvennogo oblastnogo universiteta. Seriia: "Russkaia filologiia", No. 2, pp. 159-166. (In Russian)

Nefagina, G. L. (2016). Demonicheskoe nachalo zhenskikh obrazov M. Bulgakova [Demonic Beginning of Female Images of M. Bulgakov]. Russkii iazyk v zerkale perevodov, pp. 359-367. (In Russian) 
The article was submitted on 05.06.2020

Поступила в редакцию 05.06.2020

\section{Ким Сунггеон,}

аспирант,

Казанский федеральный университет, 420008, Россия, Казань,

Кремлевская, 18.

kimgun18@mail.ru
Kim Sunggeon,

graduate student,

Kazan Federal University,

18 Kremlyovskaya Str.,

Kazan, 420008, Russian Federation.

kimgun18@mail.ru 